\title{
Sulfidation of organic matter associated with gold mineralization, Pueblo Viejo, Dominican Republic
}

\author{
Richard M. Kettler* ${ }^{*}$, Geoffrey S. Waldo $\dagger$, James E. Penner-Hahn $\dagger$, \\ Philip A. Meyers* and Stephen E. Kesler* \\ *Department of Geological Sciences, University of Michigan, Ann Arbor, MI 48109-1063, U.S.A. \\ $\dagger$ Department of Chemistry, University of Michigan, Ann Arbor, MI 48109-1055, U.S.A.
}

\begin{abstract}
The Pueblo Viejo district is one of the largest producers of precious metals in the world, yielding more than $11,000 \mathrm{~kg}$ of Au annually. Gold mineralization at Pueblo Viejo is hosted in spilite, and coarse clastic and finely laminated, fine grained carbonaceous sedimentary rocks of the Lower Cretaceous Los Ranchos Formation. Mineralization was accompanied by sulfidation as evidenced by (1) the occurrence of siderite distal to mineralization and pyrite proximal to mineralization, (2) increased S/Fe ratios associated with Au mineralization, (3) the occurrence of native $S$ in and adjacent to mineralization, and (4) the presence of sulfidized organic matter (organo-S compounds) in mineralized rocks. Organic matter in the carbonaceous sedimentary rocks comprises vitrinite and pyrobitumen. Rock-Eval pyrolysis data indicate that this organic matter is overmature $(\mathrm{HI}<55)$. The organic matter is S-rich (up to $14 \mathrm{wt} \%$ $\mathrm{S}$ ) in rocks where all Fe has been sulfidized to pyrite. X-ray absorption near edge structure (XANES) analysis indicates that the $\mathrm{C}$-bonded $\mathrm{S}$ is thiophenic. Early disseminated Au mineralization is postulated to have occurred in response to sulfidation of ferrous Fe to form pyrite. The consequent decline in the activity of $\mathrm{H}_{2} \mathrm{~S}$ in the mineralizing fluid would have destabilized Au bisulfide complexes and caused deposition of gold. The restriction of S-rich organic matter to rocks in which all Fe occurs as pyrite indicates that sulfidation of organic matter postdates sulfidation of ferrous $\mathrm{Fe}$ and therefore, deposition of much of the Au.
\end{abstract}

\section{INTRODUCTION}

Although thermal alteration of organic matter in hydrothermal systems is a well documented phenomenon (e.g. SIMONEIT, 1988; ILCHIK et al., 1986, other papers in this issue), descriptions of chemical interaction between organic matter and hydrothermal fluids are scarce. Research discussing the chemical interaction between organic matter and hydrothermal fluids has been confined largely to alteration of organic matter associated with base metal mineralization (e.g. Powell and Macqueen, 1984; MaCQUeEN and Powell, 1983; Püttmann et al., 1988). This is remarkable because organic matter occurs in a wide variety of ore deposits and hydrothermal systems and it is the chemical interaction between rocks and hydrothermal fluids that causes metal leaching and deposition. If we are to understand the association between many ore deposits and organic Ccontaining sedimentary rocks, we must understand the effects of interaction between hydrothermal fluids and organic matter.

Sulfidation, which is the addition of reduced $S$ to the components in a rock, is a type of fluid-rock interaction that is of great interest to both inorganic and organic geochemists. Evidence for sulfidation was noted in early work at Pueblo Viejo when KeSLER et al. (1981) reported that organic matter in mineralized rock contained S. Later work (KETTLER et al., 1990) has documented sulfidation of inorganic components and demonstrated that this sulfidation was

$\ddagger$ Present address: Department of Geology, University of Nebraska, Lincoln, NE 68588-0340, U.S.A. associated with the precious metal deposition: These observations prompted us to examine the organic matter and its alteration by S-rich hydrothermal fluids with several specific questions in mind. Does sulfidation of organic matter occur in hydrothermal systems? If so, what S-bearing functional groups are formed? What is the relation between sulfidation of organic matter and sulfidation of metals? Can sulfidation of organic matter effect precious metal deposition? The research reported here is part of a larger study of alteration and mineralization in the Pueblo Viejo Au-Ag district in the Dominican Republic. In this paper we document hydrothermal sulfidation of organic matter in the Au-Ag deposits of the Pueblo Viejo district, Dominican Republic. We also identify the S-bearing functional group in the organic matter and discuss the importance of organic matter sulfidation to precious metal mineralization.

\section{ANALYTICAL METHODS}

The objectives of the analytical work in this study were to assess the thermal maturity of the organic matter, determine the content and distribution of $S$ in the organic matter and to identify the S-bearing functional group or groups in the organic matter.

To assess thermal maturity, Rock-Eval pyrolysis analyses were performed on a Delsi-Nermag Rock-Eval II pyrolysis instrument. Approximately $100 \mathrm{mg}$ of coarsely ground sample was heated in helium from 250 to $550^{\circ} \mathrm{C}$ at a rate of $25^{\circ} \mathrm{C} / \mathrm{min}$. Nomenclature and data reduction follow ESPATILIÉ et al. (1977).

Sulfur analyses were made using a fully automated CAMECA Camebax electron microprobe. The beam current was $10 \eta \mathrm{A}$ with a $15 \mathrm{keV}$ accelerating voltage. Pyrite 
was used as the standard for $S$ determinations. The location of the peaks for C-bonded S and pyrite S differed by 0.0005 $\AA$ in their wavelength dispersive spectra. This difference in peak location, although the basis for the XANES analysis, has a very small effect on the $\mathbf{S}$ determinations. The $\mathbf{S}$ contents reported here (Table 2$)$ are low $(<5 \%$ of the measured value) as a result of this systematic error. Two procedures for data reduction were used. In low-S samples $(<2 \% \mathrm{~S})$ the $\mathrm{C}$ content of the macerals was fixed at $99 \%$. In high-S samples $(>2 \% \mathrm{~S})$ the $\mathrm{C}$ content was determined by difference after determination of the $S$ contents. While the $C$ contents used are approximate, they provide a realistic matrix for ZAF corrections during data reduction.

The S-bearing functional group was identified using XANES analysis. Organic matter-pyrite separates for XANES analysis were made by dissolving a sample of ore in concentrated $\mathrm{HCl}$ for $24 \mathrm{~h}$ followed by reaction with $\mathrm{HF}$ for 1 week at room temperature. Spent HF was decanted daily and replenished with fresh HF. The sample was stirred daily with a polypropylene stirring rod. After dissolution of the silicate matrix was complete the sample was rinsed with distilled water to remove HF, and reacted with a solution of $1 \mathrm{M} \mathrm{CrCl}_{2}$ in $0.5 \mathrm{~N} \mathrm{HCl}$ to remove pyrite. This treatment was continued for a week with the $\mathrm{CrCl}_{2}$ solution being changed daily. Pyrite removal was not complete. The separates contained all organic matter that was insoluble in $\mathrm{HCl}$ and $\mathrm{HF}$.

Solid samples were ground to an extremely fine powder and dispersed thinly on mylar tape (containing a S-free adhesive). The S K-edge spectra were measured using the 8pole wiggler beam line VII-3 at the Stanford Synchrotron Radiation Laboratory (SSRL), under dedicated conditions ( $3 \mathrm{GeV}, 30-50 \mathrm{~mA}$ ) with a Si(111) double crystal monochromator. The monochromator was detuned $80 \%$ to eliminate higher harmonics from the X-ray beam.

The data were collected as fluorescence excitation spectra using an ionization chamber of the Stern-Heald type as the fluorescence detector (STERN et al., 1982). The X-ray beam path and incident beam ion chamber were filled with He; the fluorescence ion chamber contained $\mathrm{N}_{2}$. The energy was calibrated by reference to the "white-line" maximum for $\mathrm{Na}_{2} \mathrm{SO}_{4}$, assigned as $2482.8 \mathrm{eV}$. Reproducibility of the energy calibration, determined by comparison of duplicate measurements for selected model compounds, was better than $0.15 \mathrm{eV}$.

All spectra were normalized and placed on a quasiabsolute absorption scale by scaling the data and fitting a single low-order polynomial to the pre-edge and post-edge regions. The data in these regions were constrained to fit tabulated X-ray absorption cross sections (McMAsTER et al., 1969). Normalized fluorescence spectra were then corrected for the line-broadening and attenuating effects of self-absorption with a general expression for fluorescence intensity as a function of sample elemental composition, incident X-ray intensity, and sample thickness (Goulon $e t$ $a l ., 1982$ ). The details of the normalization and selfabsorption correction are described by $W_{A L D O}$ and PENNERHAHN (1990).

\section{GEOLOGICAL SETTING AND MINERALIZATION IN THE PUEBLO VIEJO DISTRICT}

\section{Geology of the Pueblo Viejo district}

The Pueblo Viejo district (KesLer et al., 1981; Russell et al., 1981; Kesler et al., 1986; Russell et al., 1986) is located $50 \mathrm{~km}$ northwest of Santo Domingo in the Cordillera Central; the axial mountain range on the island of Hispaniola (Fig. 1). The Cordillera Central comprises largely the actinolitic amphibolite of the Duarte Formation and the albitequartz-sericite schist of the Maimon Formation, which appear to represent oceanic crust and some of the earliest volcanic rocks in the Greater Antilles arc, respectively (Bowin, 1975). Mineralization at Pueblo Viejo is hosted by the Cretaceous Los Ranchos Formation (KESLER et al., 1981, 1990), which is approximately $125 \mathrm{Ma}$ old; roughly the same age as metamorphism of the Duarte and Maimon Formations (Bowin, 1975; KesLer et al., 1981).

The Los Ranchos Formation consists of spilite and keratophyre flows and intrusions, and clastic sedimentary rocks derived from these rocks (KeSLER $e t$ al., 1981, 1990). Mineralization in the Pueblo Viejo district is hosted by spilite, spilite-derived coarse clastic sedimentary rocks and carbonaceous sedimentary rocks. The sedimentary rocks were deposited in a small sedimentary basin in the upper part of the Los

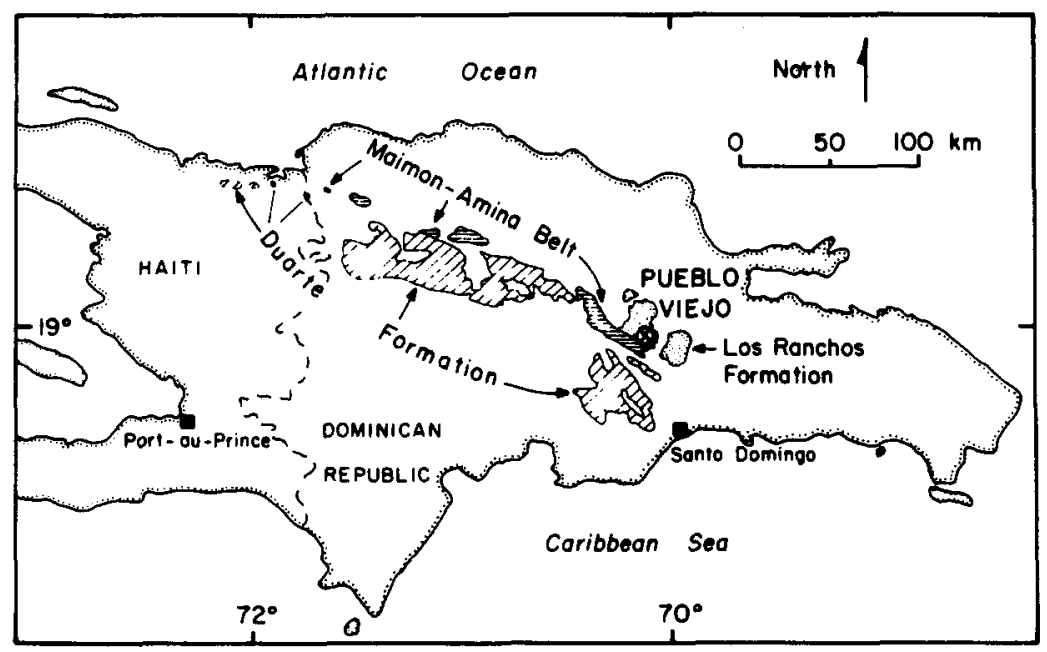

Fic. 1. Location of the Pueblo Viejo district in relation to the Duarte, Maimon and Los Ranchos Formations, Dominican Republic. 
Ranchos Formation, that has been interpreted to be a maar (Sillitoe and Bonham, 1984; Kesler et al., 1986). This basin is floored by a thick sequence of Platanal Spilite that is overlain by, and interfingers with, spilite clast conglomerates. The spilite conglomerates fine upward into feldspathic arenites interbedded with finely laminated, black siltstones which have been referred to as the "carbonaceous sediments" (KESLER et al., 1981). RUSSEl et al. (1986) described abrupt lateral facies changes between conglomerates and the carbonaceous sedimentary rocks and suggested that the present basin outline approximates its original geometry on the north and west sides.

\section{Mineralization at Pueblo Viejo}

The two largest orebodies at Pueblo Viejo are Moore and Monte Negro, which are located on the flanks of the sedimentary basin (Fig. 2). Mineralization comprises native $\mathrm{Au}$ and electrum with pyrite,
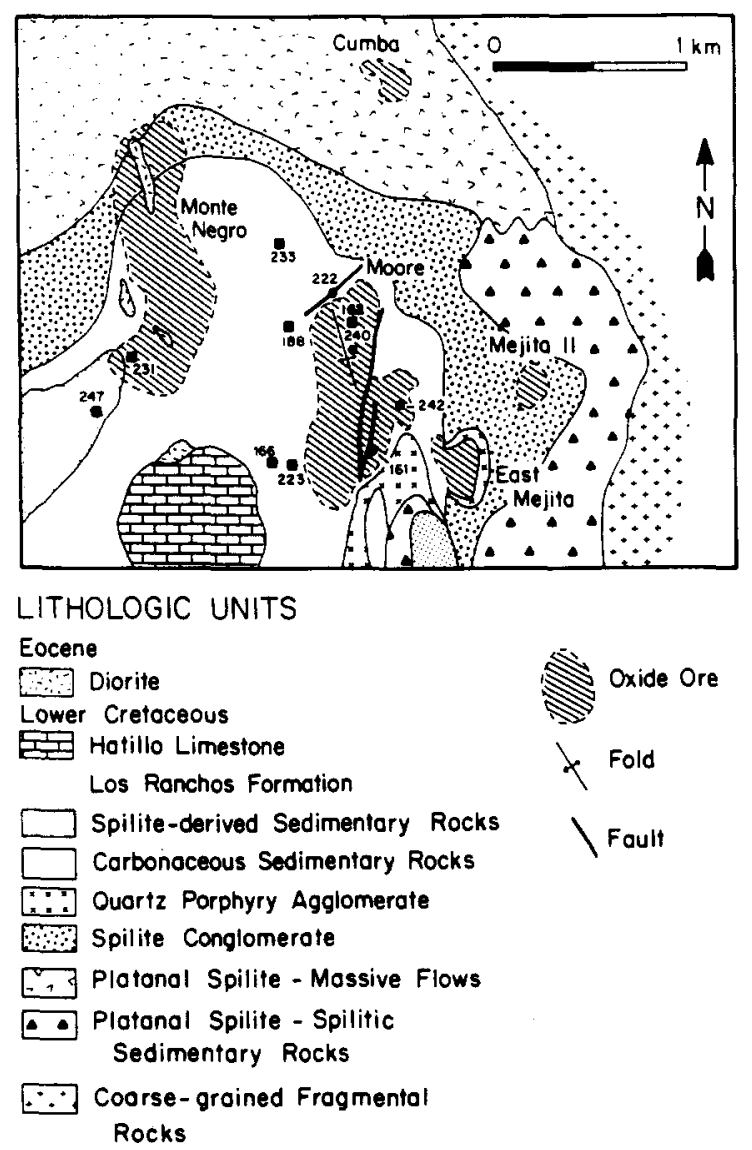

FIG. 2. Geological map of the Pueblo Viejo district showing outline of the oxidized portions of the Moore. Monte Negro, East Mejita, Mejita 11 and Cumba orebodies. Diamond drill holes that have intersected sideritic sedimentary rocks are indicated by squares. Other diamond drill holes referred to in the text are labelled. The DDH prefix to the drill hole numbers that appears in tables and in the text has been omitted from this figure. sphalerite, enargite, and lesser amounts of bournonite, chalcostibite, tennantite-tetrahedrite and boulangerite (HARTLEY and WICK, 1979; KesLer et al., 1981; Russell et al., 1986). Sulfide mineralization occurs in veins and as disseminations. At shallow depths the sulfide mineralization has been oxidized by weathering. To date only the oxidized ore has been mined. The oxidized portion of the Moore deposit contains $30 \mathrm{Mt}$ of ore with an average grade of $3.8 \mathrm{ppm} \mathrm{Au}$ and $21.0 \mathrm{ppm} \mathrm{Ag} \mathrm{(Russell} \mathrm{et} \mathrm{al.,}$ 1986). The unweathered portion of the Moore deposit contains $64 \mathrm{Mt}$ of mineralized rock with an average grade of $3.51 \mathrm{ppm} \mathrm{Au}$ and $19.1 \mathrm{ppm} \mathrm{Ag.} \mathrm{In}$ the Monte Negro system the oxidized orebody contains $14 \mathrm{Mt}$ of ore with average grades of $3.35 \mathrm{ppm} \mathrm{Au}$ and $7.6 \mathrm{ppm} \mathrm{Ag}$ while $37 \mathrm{Mt}$ of unweathered mineralized rock average $3.95 \mathrm{ppm} \mathrm{Au}$ and $22.4 \mathrm{ppm} \mathrm{Ag}$. Cutoff grades are $0.8 \mathrm{ppm}$ Au in the oxidized ore and $2.5 \mathrm{ppm}$ Au in the unweathered rock (Russell et al., 1986).

Mapping of precious metal values indicates that the orebodies are funnel-shaped (KESLER et al., 1981; RUSSELl et al., 1986). The throat of the funnel is located in spilite and spilite-clast conglomerates with the orebody flaring out to a bowl-shaped geometry in the overlying carbonaceous sedimentary rocks.

\section{Relation of sulfidation to mineralization at Pueblo Viejo}

The abundance of Fe and $\mathrm{S}$ in all rocks at Pueblo Viejo as well as the mineralogy of these elements indicates that precious metal mineralization was accompanied by sulfidation. All lithologies are pyritic in and adjacent to mineralization, whereas siderite is abundant in the carbonaceous sedimentary rocks distal to mineralization (Fig. 2). Both pyrite and siderite are common products of diagenesis in organic-rich sediments, but their occurrence $<200 \mathrm{~m}$ apart in a single restricted basin requires lateral juxtaposition of methanic and $\mathrm{C}$-rich sulfidic diagenetic environments (as defined by MAYNARD, 1982); an unlikely situation. A more likely possibility is that the disseminated pyrite formed by sulfidation of siderite.

KeTtLer et al. (1990) defined the term Degree of Sulfidation (DOS):

$$
\mathrm{DOS}=\frac{\mathrm{wt} \% \mathrm{~S}}{1.15(\mathrm{wt} \% \mathrm{Fe})}
$$

to evaluate the relative importance of sulfidation versus pyrite addition in rocks at Pueblo Viejo. DOS is defined as the mass ratio of $S$ to $F e$ in the rock divided by the mass ratio of $\mathrm{S}$ to $\mathrm{Fe}$ in pyrite. Note that DOS differs from the Degree of Pyritization (DOP) defined by BERNER (1970). DOS was used rather than DOP because determinations of the amount of $\mathrm{Fe}$ soluble in $\mathrm{HCl}$ were not available.

DOS values are higher in mineralized rocks than in unmineralized rocks with values ranging from 0.25 in 
DDH-223 to 1.5 in DDH-240 (KeTtLER et al., 1990). Although it is not impossible for DOS values approaching unity to be produced by pyritization alone, the amounts of pyrite that must be added to the rock to accomplish this exceed the amounts typically observed. For example, in order to increase DOS from 0.25 to 0.9 by pyrite deposition alone, a rock that contained $5 \%$ non-sulfide Fe initially would have an $\mathrm{Fe}$ content of $>30 \%$ after pyrite deposition was complete. Iron contents exceeding $10 \%$ are rare in rocks at Pueblo Viejo although DOS values exceeding 0.95 are widespread (KETTLER et al ., 1990). Pyrite deposition alone, without sulfidation, would not produce the high DOS values observed at Pueblo Viejo. A spatial coincidence between sulfidation and Au mineralization is indicated by mapping DOS and precious metal values (KETTLER et al., 1990). These relations indicate that rocks were sulfidized during hydrothermal activity and that inorganic phases acted as sinks for $\mathrm{S}$. Having established that sulfidation of the inorganic components of the rocks occurred it is appropriate to examine the organic components of the rock for evidence of sulfidation.

\section{SULFIDATION OF ORGANIC MATTER AT PUEBLO VIEJO}

Organic matter in the carbonaceous sedimentary rocks

Organic matter in the sedimentary rocks comprises vitrinite and pyrobitumen. Coalified fragments of trees and other land plants can be observed in hand sample. Small fragments of fusinite with preserved cell walls can be observed locally in thin section (Fig.

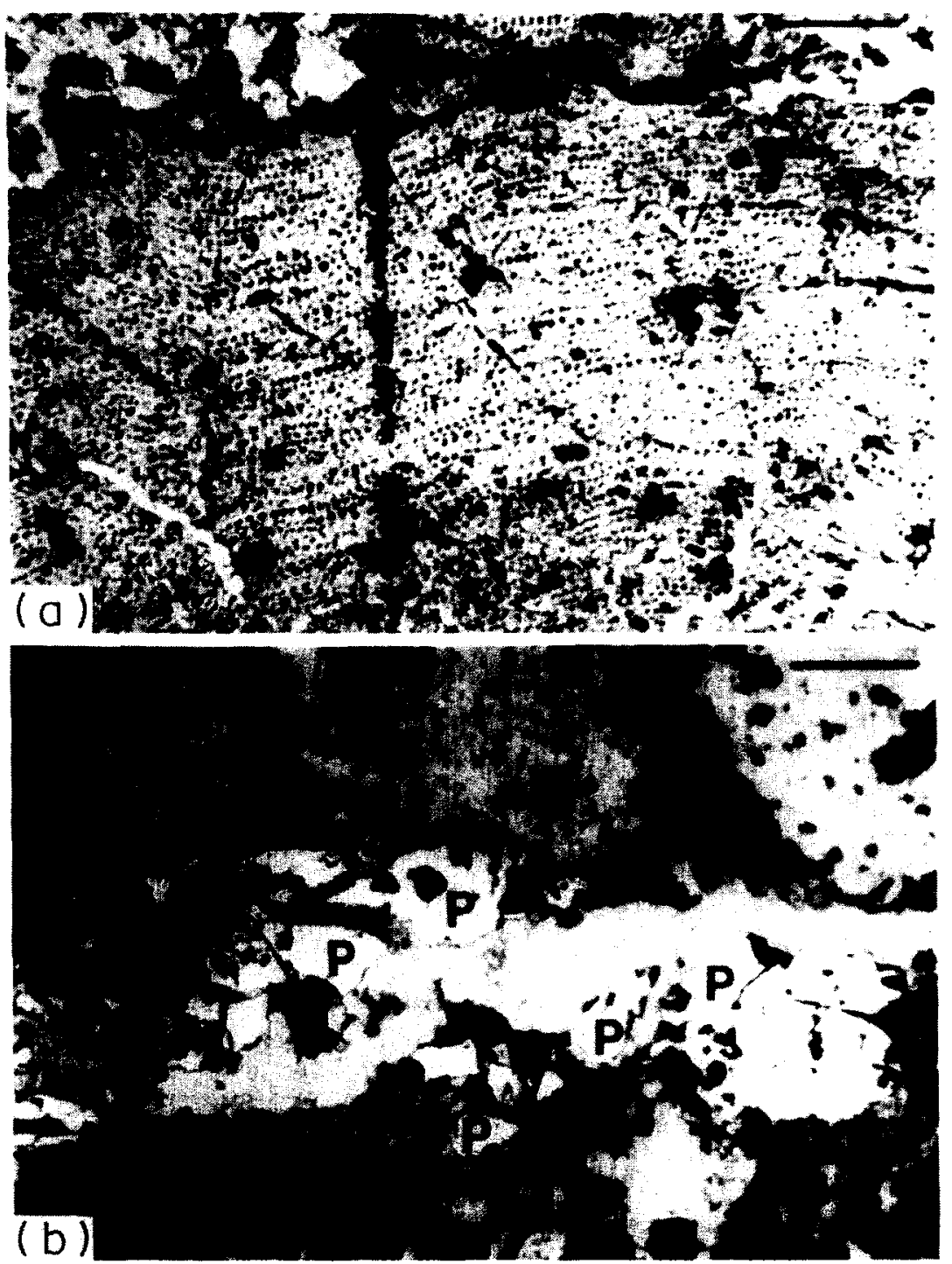

Fig. 3. Reflected light photomicrographs of organic macerals from carbonaceous sedimentary rocks at Pueblo Viejo. All photomicrographs were taken in plane-polarized light. The scale bar in each photomicrograph is $100 \mu \mathrm{m}$ long. a. Fusinite. b. The material labelled "P" that occurs along the fracture is pyrobitumen. 
3a). Pyrobitumen can be identified as structureless organic matter occurring along fractures (Fig. 3b).

The total organic C content (TOC) of unmineralized rock ranges from 1 to $2 \%$, whereas mineralized rock rarely carries more than $1 \%$ TOC. An example of this relation can be seen in Fig. 4 where the TOC and Au contents of carbonaceous sedimentary rocks in diamond drill hole 242 are plotted against depth. At $146 \mathrm{~m}$ depth, mineralized rock is juxtaposed against unmineralized rock and the TOC content increases abruptly. KESLER et al. (1981) observed that $\Sigma C: \Sigma S$ ratios were lower in mineralized rock than in unmineralized rock and ascribed this to oxidation of organic matter to $\mathrm{CO}_{2}$ during mineralization.

The organic matter in the carbonaceous sedimentary rocks is overmature. Limited Rock-Eval pyrolysis data (Table 1) indicate that virtually no bitumen is present in the rock nor are significant amounts of volatile organic matter produced during heating to $600^{\circ} \mathrm{C}$. Although the $T_{\max }$ values observed are consistent with thermally immature organic matter (Table 1), the recovery of only small amounts of volatile organic matter renders $T_{\max }$ unreliable as an indicator of thermal maturity. The relative absence of volatile organic matter in rocks that contain from 0.24 to $2.44 \%$ TOC indicates that the rocks are thermally overmature. Soxhlet extractions with a $3: 1$ ( $v: v)$ mixture of toluene and methanol failed to isolate aliphatic hydrocarbons in amounts exceeding those observed in laboratory blanks. Earlier reports

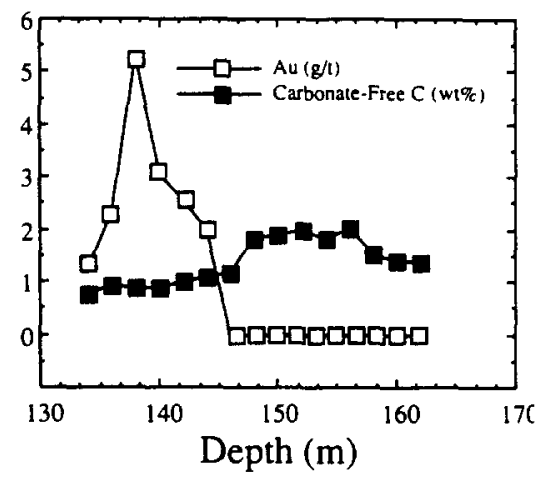

Fig. 4. Assay data for DDH-242 between depths of 134 and $162 \mathrm{~m}$ showing variation in Au grade and TOC with depth.
(KESLER et al., 1986) of small amounts of extractable aliphatic hydrocarbons, fatty acids and alcohols apparently reflect contribution from secondary sources. KESLER et al. (1986) noted a strong even to odd predominance in the fatty acid and alcohol fractions and suggested that these fractions may have been introduced after mineralization. The Soxhlet extracts obtained from samples in this work had a yellow tint which was removed by reaction with $\mathrm{Cu}$. Thus, the yellow tint was produced by native $S$ which is known to occur locally in veins at Pueblo Viejo (KesLer et al., 1981).

\section{Sulfur content of organic matter}

Knowledge of the elemental chemistry of the organic matter is required to understand chemical interaction between hydrothermal fluids and organic matter. Because the organic matter at Pueblo Viejo has a high thermal maturity, its $S$ content could be analyzed by electron microprobe without decomposition of the organic matter. Both vitrinite and pyrobitumen were analyzed by electron microprobe. Microprobe analysis of $\mathrm{S}$ allows one to map the distribution of $S$ within individual macerals and within individual samples, as well as the distribution of $\mathrm{Fe}$ or other metal cations, to confirm that the $S$ does not occur as finely disseminated inorganic sulfides.

Back-scattered electron and X-ray imaging demonstrate that the $S$ associated with organic matter does not occur as pyrite (Fig. 5). These images indicate that the $S$ is distributed through the macerals homogeneously. Moreover, only S $K_{\alpha}$ peaks are observed in wavelength dispersive spectra of organic matter; no metals are observed.

A summary of the electron microprobe data is shown in Table 2. These analyses were undertaken to determine the amount of $S$ in the organic matter, and to examine the possibility of zoning on the scale of individual macerals or in different macerals within a single thin section. The data are sufficiently precise to address these issues. Individual macerals from two samples (DDH-240-25.5 and DDH-242-209.6), which were representative of organic matter with high and low $S$ contents, respectively (Table 2), were

Table 1. Rock-Eval pyrolysis data for samples from Pueblo Vicjo

\begin{tabular}{lcccccccc}
\hline Sample & Au (g/t) & TOC & $T_{\max }$ & $S_{1}$ & $S_{2}$ & $S_{3}$ & HI & OI \\
\hline DDH-163-104 & 0.75 & 0.42 & 309 & 0.05 & 0.11 & 0.00 & 26 & 0 \\
DDH-166-020 & nil & 1.90 & 405 & 0.03 & 0.02 & 0.12 & 1 & 6 \\
DDH-167-035 & 4.25 & 2.44 & 337 & 0.16 & 0.42 & 0.03 & 17 & 1 \\
DDH-168-060 & 0.75 & 0.38 & 388 & 0.04 & 0.15 & 0.00 & 39 & 0 \\
DDH-168-225 & 0.75 & 0.24 & 396 & 0.08 & 0.13 & 0.00 & 54 & 0
\end{tabular}

All samples are black, well laminated, pyritic siltstones. Gold contents are for the 2 -m interval from which the sample was obtained. The first three digits in the sample number indicate the drill hole from which the sample was obtained, the last three digits indicate the subsurface depth in meters. 

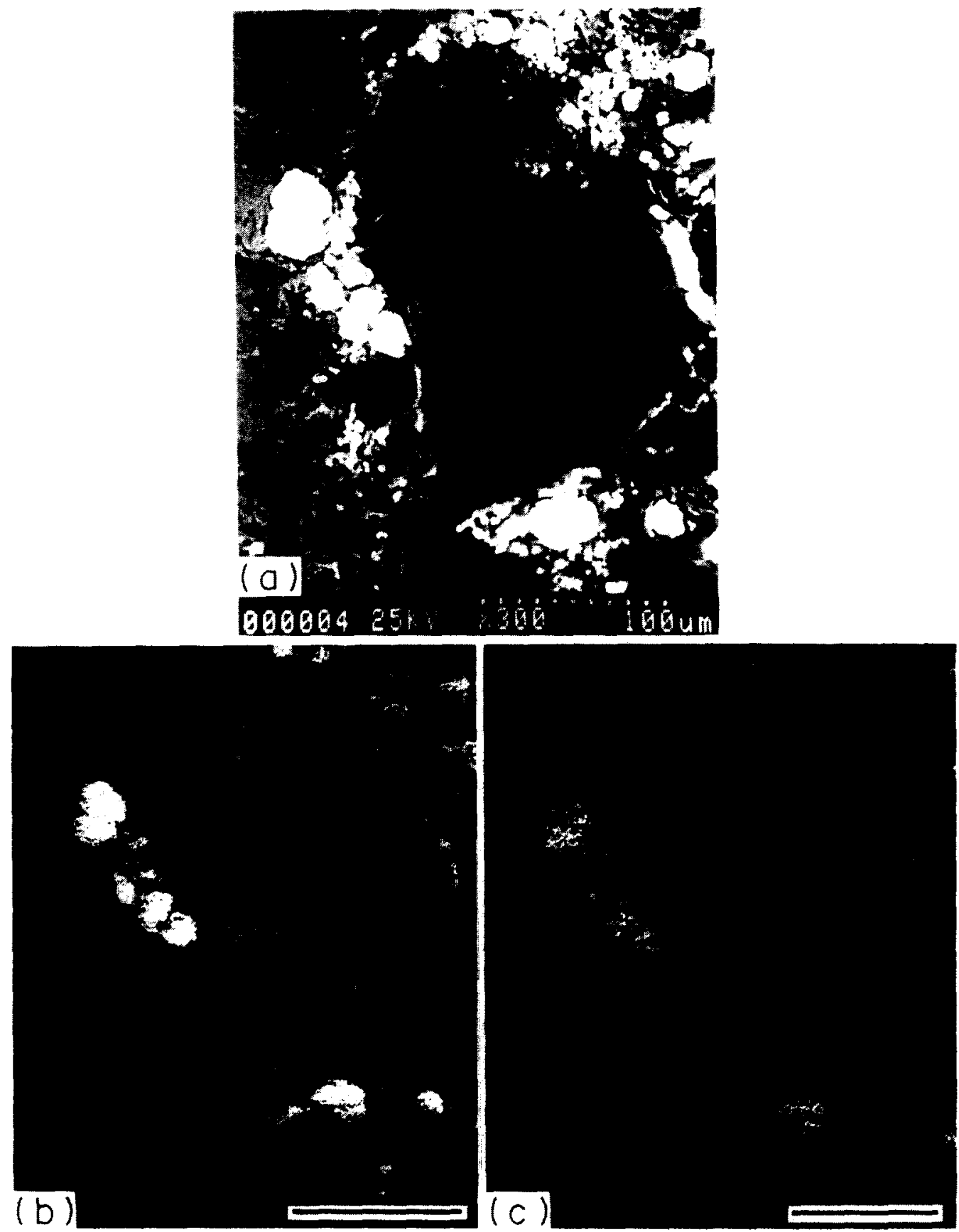

FIG. 5. Back-scattered electron (BSE) and X-ray images of organic maceral and pyrite grains. The scalc bars at the base of each image are $100 \mu \mathrm{m}$ long. a. BSE image. The organic maceral is dark and the pyrite is bright. b. X-ray image of $S K \alpha$ X-rays. Note the even distribution of $S$ through the organic maceral and the absence of Fe. c. X-ray image of Fe $K a$ and $K \beta$ X-rays.

analyzed repeatedly. The results of these replicate analyses of individual macerals indicate that the microprobe analyses have a precision of $\pm 0.4 \mathrm{wt} \%$ at the $95 \%$ confidence level. Because these analyses were made on various spots within single macerals they indicate that $\mathrm{S}$ is distributed homogeneously through the macerals; an interpretation supported by the Xray images. The data also indicate that $S$ is distributed homogeneously among different macerals within a single thin section (Table 2).
Sulfur contents $>1 \%$ are observed mostly in macerals that were obtained from rocks with ore grade Au mineralization (Fig. 6), suggesting a genetic relation between sulfidation of organic matter and Au mineralization. A second relation is shown in Fig. 7; a comparison of the $S$ content of organic macerals and the DOS of the rocks from which the samples were obtained. Figure 7 illustrates that significant $S$ has been added to the organic matter only where the DOS is greater than or equal to one. In 
Table 2. Sulfur contents of organic macerals determined by electron microprobe

\begin{tabular}{|c|c|c|c|c|c|c|c|}
\hline Sample & Maceral & $n$ & $\% \mathrm{~S}$ & Sample & Maceral & $n$ & $\% \mathrm{~S}$ \\
\hline DDH-161-78 & 1 & 2 & 9.8 & DDH-240-10.6 & 3 & 2 & 14.8 \\
\hline DDH-161-78 & 2 & 1 & 10.3 & DDH-240-10.6 & 4 & 2 & 13.4 \\
\hline DDH-161-78 & 3 & 1 & 10.1 & DDH-240-13 & 1 & 2 & 12.9 \\
\hline DDH-161-78 & 4 & 1 & 9.9 & DDH-240-13 & 2 & 1 & 12.8 \\
\hline DDH-161-78 & 5 & 1 & 9.3 & DDH-240-13 & 3 & 1 & 12.1 \\
\hline DDH-161-78 & 6 & 1 & 9.6 & DDH-240-25.5 & 1 & 17 & 13.9 \\
\hline DDH-161-78 & 7 & 1 & 9.6 & DDH-240-70.9 & 1 & 8 & 9.6 \\
\hline DDH-161-85 & 1 & 1 & 10.0 & DDH-240-70.9 & 2 & 3 & 9.8 \\
\hline DDH-161-85 & 4 & 2 & 9.9 & DDH-240-70.9 & 3 & 4 & 9.6 \\
\hline DDH-161-85 & 5 & 2 & 10.2 & DDH-240-70.9 & 4 & 1 & 9.7 \\
\hline $\mathrm{DDH}-161-85$ & 6 & 1 & 10.4 & DDH-240-70.9 & 5 & 1 & 9.8 \\
\hline DDH-161-85 & 7 & 1 & 10.5 & DDH-240-70.9 & 6 & 4 & 9.7 \\
\hline DDH-161-85 & 9 & 1 & 10.5 & DDH-240-80.1 & 1 & 2 & 11.2 \\
\hline DDH-161-103 & 1 & 2 & 10.5 & DDH-240-80.1 & 2 & 3 & 11.3 \\
\hline DDH-161-103 & 2 & 1 & 10.7 & DDH-240-80.1 & 3 & 1 & 11.7 \\
\hline DDH-161-103 & 3 & 1 & 9.7 & DDH-240-80.1 & 4 & 1 & 11.6 \\
\hline DDH-161-103 & 4 & 1 & 10.1 & DDH-240-84.2 & 1 & 1 & 8.2 \\
\hline DDH-161-103 & 5 & 1 & 10.4 & DDH-240-84.2 & 2 & 2 & 8.0 \\
\hline DDH-161-103 & 6 & 1 & 10.2 & DDH-240-84.2 & 3 & 1 & 8.0 \\
\hline DDH-161-103 & 7 & 1 & 10.4 & DDH-240-84.2 & 4 & 2 & 8.6 \\
\hline DDH-161-103 & 8 & 1 & 10.2 & DDH-240-88.5 & 1 & 7 & 7.0 \\
\hline DDH-166-53 & 1 & 2 & 0.6 & DDH-240-88.5 & 2 & 2 & 7.2 \\
\hline DDH-166-53 & 2 & 1 & 0.6 & DDH-240-88.5 & 3 & 1 & 7.3 \\
\hline DDH-166-53 & 3 & 1 & 0.6 & DDH-240-98.3 & 1 & 1 & 1.5 \\
\hline DDH-166-53 & 4 & 1 & 0.6 & DDH-240-98.3 & 2 & 1 & 1.5 \\
\hline DDH-166-53 & 5 & 1 & 0.6 & DDH-240-98.3 & 3 & 1 & 1.5 \\
\hline DDH-166-53 & 6 & 1 & 0.6 & DDH-240-98.3 & 4 & 1 & 1.4 \\
\hline DDH-166-71 & 1 & 1 & 0.6 & DDH-240-125 & 1 & 3 & 4.1 \\
\hline DDH-166-71 & 2 & 1 & 0.6 & DDH-240-125 & 2 & 2 & 4.1 \\
\hline DDH-166-71 & 3 & 1 & 0.6 & $\mathrm{DDH}-240-125$ & 3 & 1 & 4.0 \\
\hline DDH-166-71 & 4 & 1 & 0.7 & DDH-240-125 & 4 & 1 & 4.1 \\
\hline DDH-222-43.6 & 1 & 1 & 1.4 & DDH-240-125 & 5 & 1 & 4.1 \\
\hline DDH-222-43.6 & 2 & 1 & 1.4 & DDH-240-125 & 6 & 1 & 4.0 \\
\hline DDH-222-43.6 & 3 & 3 & 1.5 & DDH-242-70.45 & 1 & 2 & 11.7 \\
\hline DDH-222-43.6 & 4 & 1 & 1.5 & DDH-242-70.45 & 2 & 1 & 11.6 \\
\hline DDH-233-32.5 & 1 & 3 & 0.7 & DDH-242-70.45 & 3 & 1 & 11.7 \\
\hline DDH-233-32.5 & 3 & 1 & 1.0 & DDH-242-70.45 & 4 & 1 & 11.4 \\
\hline DDH-233-32.5 & 4 & 1 & 0.7 & DDH-242-134.8 & 1 & 1 & 6.4 \\
\hline DDH-233-32.5 & 5 & 1 & 0.8 & DDH-242-134.8 & 2 & 1 & 7.5 \\
\hline DDH-233-41.5 & 1 & 2 & 0.5 & DDH-242-134.8 & 3 & 1 & 7.4 \\
\hline DDH-233-41.5 & 2 & 1 & 0.6 & DDH-242-134.8 & 4 & 1 & 6.8 \\
\hline DDH-233-41.5 & 3 & 1 & 0.5 & DDH-242-196.5 & 1 & 3 & 1.1 \\
\hline DDH-233-41.5 & 4 & 1 & 0.6 & DDH-242-196.5 & 2 & 1 & 1.1 \\
\hline DDH-233-73.5 & 1 & 2 & 0.7 & DDH-242-196.5 & 3 & 1 & 1.1 \\
\hline DDH-240-10.6 & 1 & 3 & 13.1 & DDH-242-209.6 & 1 & 33 & 1.1 \\
\hline DDH-240-10.6 & 2 & 2 & 13.1 & & & & \\
\hline
\end{tabular}

The column marked " $n$ " indicates the number of analyses obtained from a particular maceral. The column marked "wt \% $S$ " is the arithmetic mean of all analyses from that maceral. Sample numbers explained in Table 1.

other words, $S$ is added to organic matter only when all $\mathrm{Fe}$ has been pyritized. This observation indicates that sulfidation of organic matter postdates sulfidation of $\mathrm{Fe}$ and that organic matter represents an additional sink for $\mathrm{S}$ beyond that provided by metals. The relation between organic matter that contains abundant $S$ and $A u$ mineralization probably reflects the higher average DOS of mineralized rocks.

\section{XANES analysis of organic sulfur}

The S-bearing functional group in the organic matter was identified using XANES analysis. X-ray absorption spectra consist of a discontinuity in absorption at the threshold for core electron excitation ( $\mathrm{S} 1 s$ in the present case) followed by a gradual decline in absorption with increasing energy. XANES analysis utilizes the position of the absorption edge and the structure of the spectrum immediately adjacent to the absorption edge. It has been shown that the position of the $\mathrm{S} \mathrm{K}$-edge is dependent on the formal oxidation state of the S (SPIRo et al., 1984; Hedman et al., 1986). The type of S-bearing functional group will also control the structure observed immediately above the edge (SpIro et al., 1984). To a limited extent XANES can discriminate between different $\mathrm{S}$-bearing functional groups having 


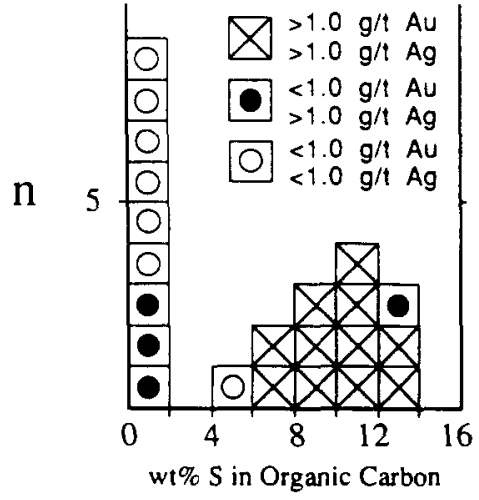

FIG. 6. Histogram showing relation between $S$ content of organic matter and Au content of the 2-m drill hole sample from which the sample was obtained. Sulfur content was determined by taking the arithmetic mean of all analyses of macerals from each interval.

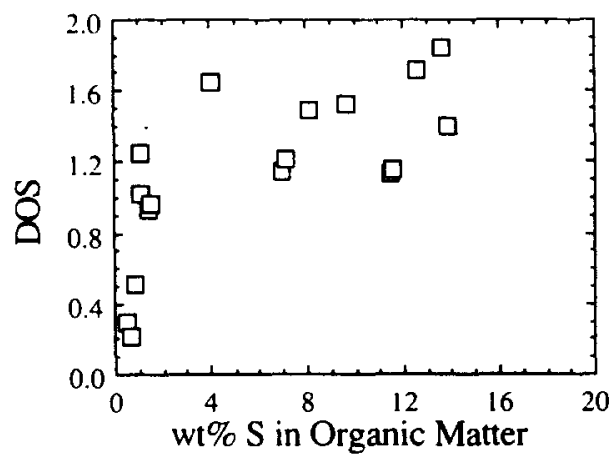

FIG. 7. Relation between $S$ content of organic matter and degree of sulfidation (DOS) for the 2-m interval from which each sample was obtained. Sulfur content of the organic matter was determined as in Fig. 6. Note that five samples that appear in Fig. 6 do not appear here because total Fe and $S$ data are not available for those intervals.

the same $\mathrm{S}$ oxidation state based on the change in the shape of the edge.

The normalized XANES of the organic matterpyrite separate is shown in Fig. 8. In addition to the absorption edge for pyritic S $(2473 \mathrm{eV})$ a higher energy feature can be observed at $2474 \mathrm{eV}$. The kerogen pyrite separate was fit with linear combinations of model compounds, using a least-squares procedure. Model compounds included pyrite, native $S$, disulfides, sulfides, thiols, thiophenes, sulfoxides, and sulfate. The three models for which the best fits were obtained considered sulfide, sulfoxide and thiophenic functional groups (Fig. 9). The best fit was obtained for a combination of pyritic and thiophenic (2474 eV feature) S (Fig. 9). Native $S$ would exhibit an absorption edge at $2472 \mathrm{eV}$, however, the native $S$ is removed during sample preparation when pyrite is removed by reduction using $\mathrm{CrCl}_{2}$. The occurrence of a thiophene functional group is consistent with the high maturity and aromatic nature of the organic matter.

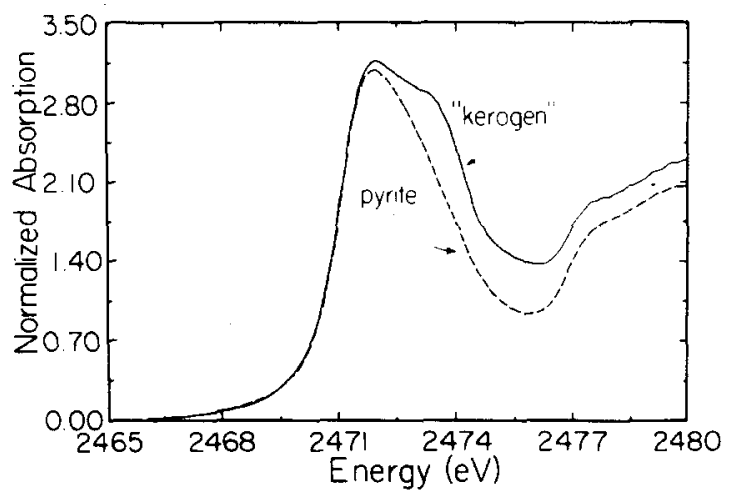

Fig. 8. Normalized XANES spectra for neat pyrite (dashed line) and for organic matter-pyrite separate (solid line labelled "kerogen") from sample DDH-240-25.5. The pyrite-S peak is evident at $\sim 2472 \mathrm{eV}$; a C-bonded S peak can be seen at $\sim 2474 \mathrm{eV}$.

\section{Significance of hydrothermal sulfidation to gold mineralization}

The data presented above demonstrate that organic matter was sulfidized during hydrothermal activity, but they do not show how sulfidation is related to precious metal mineralization. This last point can be resolved by considering the factors that control precious metal transport and deposition.

Precious metals are transported as aqueous complexes in hydrothermal systems (BARNEs, 1979). The amount of $\mathrm{Au}$ or Ag that can be transported to the site of deposition and its speciation during transport depend on:

(1) the abundance of complexing ligands and of cations that might compete with $\mathrm{Au}$ for these ligands and,

(2) the affinity of the precious metal and competing cations for complexing ligands.

Precious metal deposition requires a mechanism that will destabilize precious metal-ligand complexes.

Experimental (SHENBERGER and BARNES, 1987; Seward, 1973) and theoretical (Helgeson, 1969) work has established that Au can be transported by chloride or sulfide complexes. The ore depositing process can be illustrated graphically using equilibrium constants for the formation of Au complexes and reactions among mineral phases (Table 3, Fig. 10). Prior to reaction with unaltered carbonaceous sedimentary rocks the hydrothermal fiuid at Pueblo Viejo would have had a composition near the black dot (KeSLER et al., 1981) and could have carried significant amounts of $\mathrm{Au}$. Reaction with the siderite in the carbonaceous sedimentary rocks would have reduced the fluid and depressed the activity of $\mathrm{H}_{2} \mathrm{~S}$ during pyritization of ferrous $\mathrm{Fe}$ following the reaction:

$$
\begin{aligned}
\mathrm{H}^{+}+4 \mathrm{FeCO}_{3} & +7 \mathrm{H}_{2} \mathrm{~S}+\mathrm{HSO}_{4}^{-} \\
& =4 \mathrm{FeS}_{2}+4 \mathrm{CO}_{2}+8 \mathrm{H}_{2} \mathrm{O} .
\end{aligned}
$$

When plotted in $\log a_{\mathrm{O}}-\log a_{\mathrm{H}_{2} \mathrm{~S}}$ space the relevant 
reaction is:

$\mathrm{FeCO}_{3}+2 \mathrm{H}_{2} \mathrm{~S}+0.50_{2}=\mathrm{FeS}_{2}+\mathrm{CO}_{2}+2 \mathrm{H}_{2} \mathrm{O}$

which has a slope of -4 in $\log a_{\mathrm{O}_{2}}-\log a_{\mathrm{H}_{2} \mathrm{~S}}$ space. As the activity of $\mathrm{H}_{2} \mathrm{~S}$ and $\mathrm{O}_{2}$ declined $\mathrm{Au}$ deposition would occur through the reaction:

$$
0.5 \mathrm{H}_{2} \mathrm{O}+\mathrm{Au}(\mathrm{HS})_{2}^{-}+\mathrm{H}^{+}=2 \mathrm{H}_{2} \mathrm{~S}+\mathrm{Au}+0.250_{2} \text {. }
$$

The fluid reaction path crosses the $\mathrm{Au}$ solubility contours at a high angle in $\log a_{\mathrm{O}_{2}}-\log a_{\mathrm{H}_{2} \mathrm{~S}}$ space (Fig. $10)$ because both reduced $S$ and oxidants are consumed during pyritization of siderite. After all the siderite has been converted to pyrite, subsequent packets of fluid passing through the rock will not be
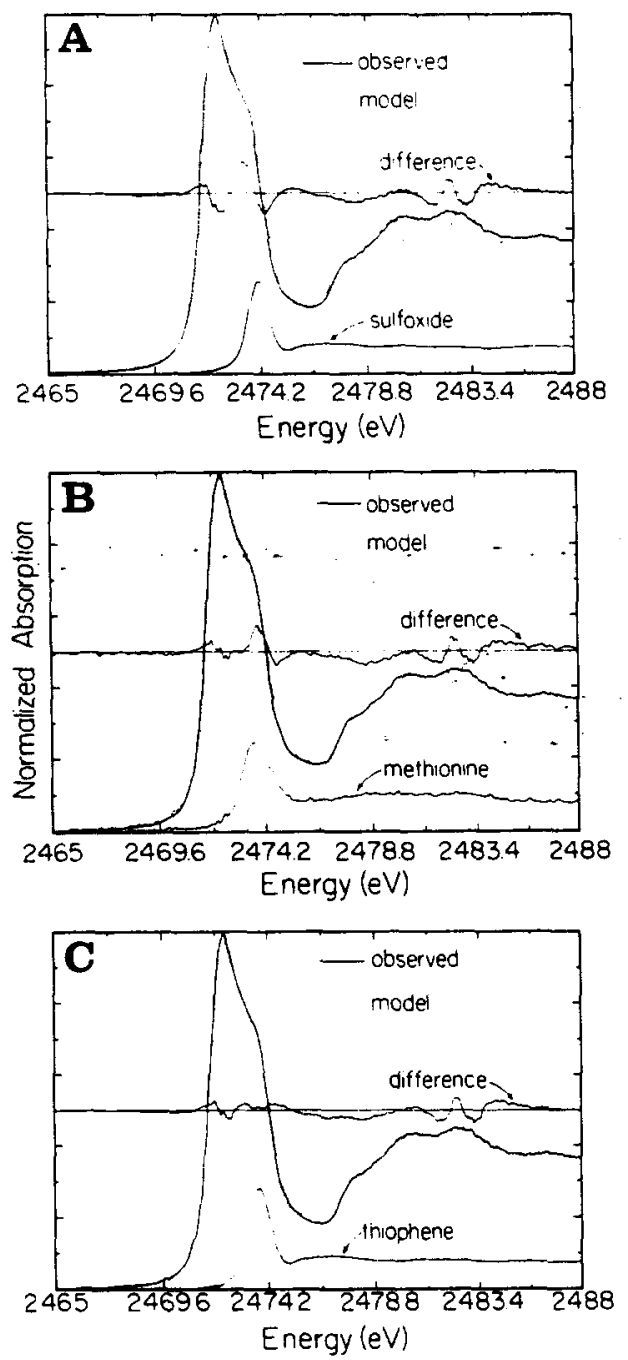

FIG. 9. Comparison of normalized XANES spectrum obtained for organic matter-pyrite separate (bold solid line) with model spectra (dotted line). The model spectra are mixtures of pyrite, the functional group or compound shown at the bottom of each figure, and small amounts of sulfate. The solid fine line is the arithmetic difference between the observed spectrum and the model spectrum. The best fit is obtained in Fig. 9C where the S-bearing functional group is thiophene.

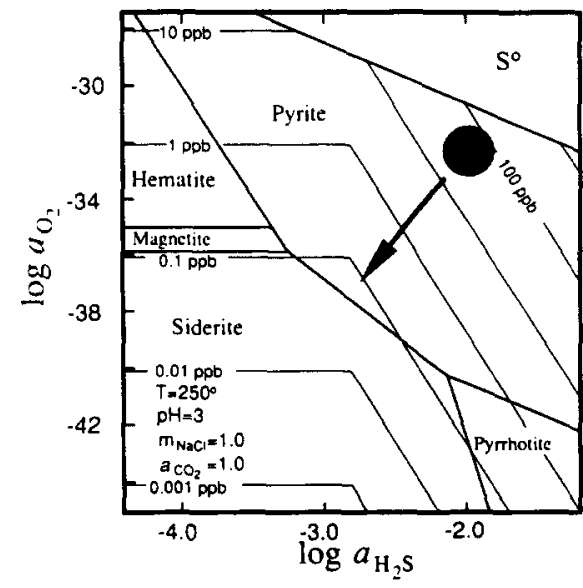

Fig. 10. $\log a_{\mathrm{O}_{2}}-\log a_{\mathrm{H}_{2} \mathrm{~S}}$ diagram used to model sulfidation and $\mathrm{Au}$ deposition at Pueblo Viejo. Equilibrium constants used are listed in Table 3. Diagram drawn for $T=$ $250^{\circ} \mathrm{C}$, unit activity of aqueous $\mathrm{CO}_{2}, \mathrm{pH}=3$, and $\mathrm{NaCl}$ concentration of $1 \mathrm{~m}$. The standard state for $\mathrm{O}_{2}$ and $\mathrm{H}_{2} \mathrm{~S}$ gas is $250^{\circ} \mathrm{C}$ and 1 bar. The horizontal and sloping contours indicate $\mathrm{Au}$ solubility in $\mathrm{ppb}$; where these contours are horizontal $\mathrm{Au}$ is complexed by chloride, predominantly; where the contours are sloping Au bisulfide predominates. Data of KESLER et al. (1981) indicate that the solution chemistry would have been near the black dot prior to reaction with sideritic sedimentary rocks. Reaction with siderite would buffer the system on the siderite-pyrite join and "drag" the solution chemistry across Au solubility contours along the path designated by the arrow. Thus, reaction of the fluid with siderite would result in Au deposition. After all siderite had been pyritized the system would not be buffered and subsequent packets of fluid would not deposit Au by this mechanism.

buffered by siderite and will not deposit $\mathrm{Au}$ by this mechanism. When pyritization is complete, Au deposition by sulfidation ceases. The details of gold deposition are much more complex than presented here. Figure 10 has been drawn for conditions of fixed $\mathrm{pH}$ and $a_{\mathrm{CO}_{2}}$ but reactions (2) and (4) both consume acid while reaction (2) also produces $\mathrm{CO}_{2}$. Even though variations in $\mathrm{pH}$ and $a_{\mathrm{CO}_{2}}$ will affect details of the Au deposition the chemographics of the system are presented fairly in Fig. 10.

Although sulfidation of organic matter is more difficult to model because the structures of the reactant and product organic compounds cannot be characterized precisely, some generalizations can be made. Specifically, it can be shown that production of thiophenic functional groups is an oxidative process except where a S-bearing functional group replaces an oxygen-bearing one. At Pueblo Viejo the final product is an aromatic kerogen with thiophenic functional groups, so it is appropriate to consider several types of reactions that can produce thiophenic functional groups. These reactions are considered only to illustrate the chemographics of sulfidation reactions; they do not represent specific reactions purported to have occurred. Each of the reactions is written using $\mathrm{H}_{2} \mathrm{~S}$ as the $\mathrm{S}$ species. This is done for the purposes of plotting the reactions in chemical space; it is possible 
Table 3. Equilibrium constants used to construct Fig. 10

\begin{tabular}{|c|c|c|}
\hline Reaction & $\log \mathrm{K}$ at $250^{\circ} \mathrm{C}$ & Source \\
\hline $\begin{array}{l}\mathrm{H}_{2} \mathrm{~S}=\mathrm{H}^{+}+\mathrm{HS}^{-} \\
\mathrm{H}_{2} \mathrm{O}=\mathrm{H}_{2}+0.50_{2} \\
\mathrm{~S}^{\circ}+\mathrm{H}_{2} \mathrm{O}=0.50_{2}+\mathrm{H}^{+}+\mathrm{HS}^{-} \\
\mathrm{Fe}_{3} \mathrm{O}_{4}+8 \mathrm{H}^{+}=\mathrm{Fe}^{2+}+2 \mathrm{Fe}^{3+}+4 \mathrm{H}_{2} \mathrm{O} \\
\mathrm{Fe}_{2} \mathrm{O}_{3}+6 \mathrm{H}^{+}=2 \mathrm{Fe}^{3+}+3 \mathrm{H}_{2} \mathrm{O} \\
\mathrm{Fe}^{3+}+0.5 \mathrm{H}_{2} \mathrm{O}=\mathrm{H}^{+}+0.250_{2}+\mathrm{Fe}^{2+} \\
\mathrm{Fe}_{0.875} \mathrm{~S}+\mathrm{H}^{+}=0.625 \mathrm{Fe}^{2+}+0.25 \mathrm{Fe}^{3+}+\mathrm{HS}^{-} \\
\mathrm{FeCO}_{3}+\mathrm{H}^{+}=\mathrm{Fe}^{3+}+\mathrm{HCO}_{3}^{-} \\
\mathrm{FeS}_{2}+\mathrm{H}_{2} \mathrm{O}=2 \mathrm{HS}^{-}+0.50_{2}+\mathrm{Fe}^{3+} \\
\mathrm{CO}_{2}+\mathrm{H}_{2} \mathrm{O}=\mathrm{H}^{+}+\mathrm{HCO}_{3}^{-} \\
\mathrm{AuCl} \mathrm{Cu}_{2}^{-}=\mathrm{Au}^{+}+2 \mathrm{Cl}^{-} \\
\mathrm{Au}+0.250_{2}+\mathrm{H}^{+}=\mathrm{Au}+0.5 \mathrm{H}_{2} \mathrm{O} \\
\mathrm{Au}+\mathrm{H}_{2} \mathrm{~S}+\mathrm{HS}^{-}=\mathrm{Au}(\mathrm{HS})_{2}^{-}+0.5 \mathrm{H}_{2}\end{array}$ & $\begin{array}{l}-7.72 \\
-22.96 \\
-25.02 \\
-5.51 \\
-9.37 \\
-0.22 \\
-8.83 \\
-3.77 \\
-35.88 \\
-7.76 \\
-6.2 \\
-3.52 \\
-1.61\end{array}$ & $\begin{array}{l}(1) \\
(1) \\
(1) \\
(1) \\
(1) \\
(1) \\
(1) \\
(1) \\
(1) \\
(1) \\
(2) \\
(2) \\
(3)\end{array}$ \\
\hline
\end{tabular}

Explanation of sources: (1) Data taken from file DATA0, (data0.3245R46); generated 13 August 1986. DATAO is a set of internally consistent equilibrium constants compiled for use with the EQ3 speciation code (Wolery, 1983). The equilibrium constants in DATA0 were calculated from data in SUPCRT either alone $\left(\mathrm{H}^{+}, \mathrm{H}_{2} \mathrm{O}\right.$, $\mathrm{HS}^{-}, \mathrm{O}_{2}, \mathrm{Fe}^{3+}, \mathrm{Fe}^{2+}, \mathrm{FeCO}_{3}, \mathrm{HCO}_{3}^{-}, \mathrm{Fe}_{2} \mathrm{O}_{3}, \mathrm{FeS}_{2}$ ) or in conjunction with data from Tremaine and Leblanc (1980) $\left(\mathrm{Fe}_{3} \mathrm{O}_{4}\right)$, Wagman et al. (1982) $\left(\mathrm{Fe}_{0.875} \mathrm{~S}\right)$, and SMITH and MARTELl (1976) $\left(\mathrm{CO}_{2}\right)$. SUPCRT is an internally consistent compilation of thermodynamic data produced by HeLgeson $e t$ al. (1978). Data for $S^{\circ}$ obtained from WAGMAN $e t$ al. (1982) and Robie et al. (1978). (2) Helgeson (1969). (3) Shenberger and Barnes (1986).

that other $\mathrm{S}$ species are involved in the molecular reactions. One type of reaction possible is the conversion of hexane to dimethylthiophene by the reaction:

$$
\mathrm{C}_{6} \mathrm{H}_{14}+2 \mathrm{O}_{2}+\mathrm{H}_{2} \mathrm{~S}=\mathrm{C}_{6} \mathrm{H}_{8} \mathrm{~S}+4 \mathrm{H}_{2} \mathrm{O} \text {. }
$$

This reaction has a slope of -0.5 in $\log a_{\mathrm{O}_{2}}-\log a_{\mathrm{H} 2 \mathrm{~S}}$ space, which, because saturated hydrocarbons contain the most highly reduced $\mathrm{C}$ atoms, is the maximum slope possible for sulfidation of organic matter. Using other reactants will change the slope but will not change its sign. If sulfidation is modelled by conversion of biphenyl to dibenzothiophene then the elemental sulfidation reaction will be

$$
\mathrm{C}_{12} \mathrm{H}_{10}+\mathrm{H}_{2} \mathrm{~S}+\mathrm{O}_{2}=\mathrm{C}_{12} \mathrm{H}_{8} \mathrm{~S}+2 \mathrm{H}_{2} \mathrm{O} \text {. }
$$

Because both $\mathrm{O}_{2}$ and $\mathrm{S}$ are required in equimolar proportions, the equilibrium for this reaction will have a slope of -1 in $\log a_{\mathrm{O}_{2}}-\log a_{\mathrm{H}_{2} \mathrm{~S}}$ space. Note that in both of these cases the slope of the "organic" sulfidation reaction is greater than that observed for sulfidation of siderite. Sulfidation of ketones to thiophenic functional groups would also have a slope of -1 . Finally, the steepest slopes would be produced by sulfidation of a di-ketone to a thiophenic functional group:

$$
\mathrm{C}_{6} \mathrm{H}_{10} \mathrm{O}_{2}+\mathrm{H}_{2} \mathrm{~S}=\mathrm{C}_{6} \mathrm{H}_{8} \mathrm{~S}+2 \mathrm{H}_{2} \mathrm{O} \text {. }
$$

Because this reaction requires substitution of $\mathrm{S}$ for carbonyl $\mathrm{O}$, it will be vertical in $\log a_{\mathrm{O}_{2}}-\log a_{\mathrm{H}_{2} \mathrm{~S}}$ space. Although the aromatic rings, alkanes, alkenes, or ketones will be part of a much larger kerogen structure, the important relation is the one between sulfidation and oxidation of $\mathrm{C}$ atoms. While the slope of the various reactions can be determined quantitatively, the positions of the reactions cannot be determined with the data available. The dashed lines shown in Fig. 11 are intended to represent the effects of different types of "organic" sulfidation reactions on a hydrothermal fluid. Because these dashed lines represent metastable equilibria and because the positions of these reactions cannot be determined, more extensive discussion, such as construction of a Morey-Shreinemakers' bundle, is inappropriate. All that is known of the position of the reactions that occurred at Pueblo Viejo is that they must lie at lower values of $a_{\mathrm{O}_{2}}$ and $a_{\mathrm{H}_{2} \mathrm{~S}}$ than the original fluid composition. If sulfidation occurred by reaction of native $S$ with organic matter then the fluid chemistry must have intersected the $\mathrm{S}$ condensation

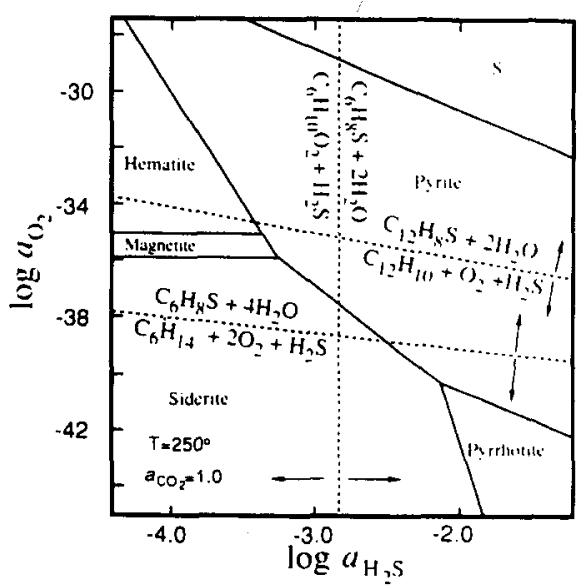

Fig. 11. $\log a_{\mathrm{O}_{2}}-\log a_{\mathrm{H}_{2} \mathrm{~S}}$ diagram illustrating the slopes of various "organic" sulfidation reactions. Conditions and standard states are the same as for Fig. 10. 
curve during sulfidation. The precursor compounds are unknown and virtually all the compound types discussed here (with the exception of biphenyl) have been suggested as precursors for the thiophenic compounds observed in oils (SINNINGHe Damsté et al., 1987, 1989; DE Roo and Hodgson, 1978).

Could sulfidation of the organic matter cause $\mathrm{Au}$ deposition? In principle, the answer is yes. The efficiency and efficacy of "organic" sulfidation as a mechanism for $\mathrm{Au}$ deposition is controlled by the position of the reactions in $\log a_{\mathrm{O}_{2}}-\log a_{\mathrm{H}_{2} \mathrm{~S}}$ space as well as by the buffer capacity of the organic matter. Because the sulfidation reactions for most types of organic compounds have negative slopes (as do all reactions for sulfidation of $\mathrm{Fe}$ ), any "organic" sulfidation reaction could contribute to Au deposition if $\mathrm{Au}$ is transported as $\mathrm{Au}(\mathrm{HS})_{2}^{-}$; those sulfidation reactions with subhorizontal slopes would contribute to Au deposition regardless of the complexing ligand. The mechanism of $\mathrm{Au}$ deposition would differ slightly between sulfidation of siderite and sulfidation of different organic compounds. Sulfidation of siderite effects $\mathrm{Au}$ deposition by reduction of aurous cations and de-sulfidation of the fluid. In contrast, because reactions for sulfidation of non-oxygenated $\mathrm{C}$ compounds have very low slopes (Fig. 11), Au deposition would be caused primarily by reduction of aurous cations, while sulfidation of diketones could contribute to Au deposition by desulfidation of the fluid. Because the buffer capacity of the organic matter is small, the quantitative effect of sulfidation of organic matter on Au grade is probably also small. One kilogram of rock with $1 \%$ TOC and $5 \% \mathrm{Fe}$ occurring as siderite can consume $1 \mathrm{~g} \mathrm{~S}$ in organic matter (assuming $10 \mathrm{wt} \% \mathrm{~S}$ in organic matter) and 56 $\mathrm{g} \mathrm{S}$ in pyrite. The ability of organic matter to buffer the oxidation state during sulfidation will similarly be low relative to the ability of $\mathrm{Fe}$ to buffer $\mathrm{O}_{2}$ content. Thus, although sulfidation of organic matter could cause $\mathrm{Au}$ deposition, sulfidation of ferrous $\mathrm{Fe}$ is a more powerful means of localizing gold mineralization in Fe-rich rocks. Sulfidation of organic matter could make a more significant contribution to gold grade in Fe-poor systems, such as hydrothermal systems hosted in limestones or dolomites.

\section{CONCLUSIONS}

At Pueblo Viejo, organic matter was sulfidized during hydrothermal alteration. The S-bearing functional group has been determined to be thiophenic through the use of XANES. The occurrence of Cbonded $S$ in rocks that had been pyritized completely indicates that sulfidation of organic matter occurred after pyritization of ferrous $\mathrm{Fe}$ was complete. Although sulfidation of organic matter could cause Au deposition, the buffer capacity of the organic matter is low relative to that for $\mathrm{Fe}$ and this process probably did not have contribute significantly to Au grade at Pueblo Viejo.

This work demonstrates that organic matter can act as a sink for components of hydrothermal fluids. It also demonstrates that sulfidation of organic matter can occur whenever all labile $\mathrm{Fe}$ has been pyritized and S-rich fluids remain extant. Sulfidation of organic matter need not be confined to any particular stage of diagenesis. Finally, it should be noted that the behavior of organic matter in hydrothermal systems cannot be assessed completely through determinations of thermal maturity, rather one must describe the alteration of organic matter and relate that alteration to the chemistry of the hydrothermal system.

Acknowledgements-The authors would like to thank $\mathrm{M}$. Seaward, N. Russell and J. Polanco for field and logistical support at Pueblo Viejo and for sharing their knowledge of the district with us. $M$. Bath provided analyses and insights at Pueblo Viejo. C. E. Henderson provided help with the electron microprobe analyses and SEM work at the University of Michigan. The Rock-Eval pyrolysis analyses were carried out by K. W. Dunham. Reviews by J. S. Leventhal, J. L. Muntean, R. R. Seal II, W. Püttmann, B. Hitchon, and an anonymous reviewer as well as conversations with $R$. E. Beane, C. N. Alpers, E. L. Shock and W. C. Kelly have helped refine and clarify the work presented here. The efforts of B. R. T. Simoneit in organizing and editing this issue are greatly appreciated.

Research on the organic geochemistry of the mineralization at Pueblo Viejo has been supported by Rosario Domincana S.A. and National Science Foundation grant EAR-8607021 to SEK and PAM. XANES studies at the University of Michigan have been supported, in part, by Chevron Oilfield Research Company. X-ray beam time was provided by the Stanford Synchrotron Radiation Laboratory which is supported by the Department of Energy and the National Institutes of Health. The SEM and electron microprobe used in this work were provided by National Science Foundation grants BSR-83-14092 and EAR-8212764 , respectively. Finally, the authors wish to thank E. J. Essene for his interest in this project, his comments and suggestions, and for alerting RMK to the interests of JEPH.

\section{REFERENCES}

Barnes H. L. (1979) Solubilities of ore minerals. In Geochemistry of Hydrothermal Ore Deposits (ed. H. L. BARNes), pp. 404-460. John Wiley.

BERNER R. A. (1970) Sedimentary pyrite formation. Am.J. Sci. 268, 1-23.

Bowin C. O. (1975) The geology of Hispaniola. In The Ocean Basins and Margins (eds A. E. M. NAIRN and F. G. STEHLI), pp. 501-552. Plenum.

De Roo J. and Hodgson G. W. (1978) Geochemical origin of organic sulfur compounds: Thiophene derivatives from ethylbenzene and sulfur. Chem. Geol. 22, 71-78.

Espatilie J., Laporte J. L., Madec M., Marquis F., Leplat P., Paulet J. and Boutefeu A. (1977) Méthode rapide de caractérisation des roches mères, de leur potentiel pétrolier et de leur degré d'évolution. Rev. Inst. fr. Pétrole. 32, 23-42.

Goulon J., Goulon-Ginet C., Cortes R. and Dubois J. M. (1982) On experimental attenuation factors of the amplitude of EXAFS oscillations in absorption, reflectivity and luminescence measurements. J. Phys. (Les Ulis, Fr.) 43, 539-548. 
Hartley J. N. and Wick O. J. (1979) Mineralogical investigation of five selected samples from the Pueblo Viejo sulfide ore. Batelle Pacific Northwest Laboratories, private report for Rosaio Dominicana, S.A.

Hedman B., Frank P., Penner-Hahn J. E., Roe A. L., Hodgson K. O., Carlon R. M. K., Brown G., Cerino J., Hettel R., Troxel T., Winick H. and YANG J. (1986) Sulfur K-edge $\mathrm{X}$-ray absorption studies using 54 pole wiggler at SSRL in undulator mode. Nucl. Instrum. Meth. Phys. Res. Sect. A A246, 797-800.

Helgeson H. C. (1969) Thermodynamics of hydrothermal systems at elevated temperatures and pressures. $A m . J$. Sci. 267, 729-804.

Helgeson H. C., Delaney J. C., Nesbitt H. W. and Bird D. K. (1978) Summary and critique of the thermodynamic properties of rock-forming minerals. Am. J.Sci. 278-A, 1-299.

IlCHIK R. P., Brimhall G. H. and Schull. H. W. (1986) Hydrothermal maturation of indigenous organic matter at the Alligator Ridge gold deposits, Nevada. Econ. Geol. 81, 113-130.

Kesler S. E., Russell N., Seaward M., Rivera J., McCurdy K., Cumming G. L. and Sutter J. F. (1981) Geology and geochemistry of sulfide mineralization underlying the Pueblo Viejo gold-silver oxide deposit, Dominican Republic. Econ. Geol. 76, 1096-1117.

Kesler S. E., Kettler R. M., Meyers P. A., Dunham K. W., Russell N., Seaward M. and McCurdy K. (1986) Relation between organic material and precious metal mineralization in the Moore orebody, Pueblo Viejo, Dominican Republic. In Organics and Ore Deposits: Proceedings of the Denver Region Exploration Geologists Society Symposium (ed. W. E. DEAN), pp. 105-110. Denver Region Exploration Geologists Society.

Kesler S. E., Russell N., Polanco J., McCurdy K. and Cumming G. L. (1990) Geology and geochemistry of the Early Cretaceous Los Ranchos Formation, a bimodal volcanic pile, Central Dominican Republic. In The Geology of Hispaniola (ed. P. MANN), Geol. Soc. Am. Spec. Paper in press.

Kettler R. M., Kesler S. E., Rye R. O. and Meyers P. A. (1990) Precious metal mineralization by sulfidation of ferrous iron in the Moore gold-silver deposit, Pueblo Viejo, Dominican Republic. In preparation.

Maynard J. B. (1982) Extension of Berner's "New geochemical classification of sedimentary environments" to ancient sediments. J. Sedim. Petrol. 52, 1325-1331.

Macqueen R. W. and Powell T. G. (1983) Organic geochemistry of the Pine Point lead-zinc ore field and region, Northwest Territories, Canada. Econ. Geol. 78, 1-25.

McMaster W. H. Kerr Del Grande N., Mallett J. H. and Hubbel J. H. (1969) Compilation of X-ray cross sections. UCRL-50174, Sec II Rev. 1.350 pp.

Powell T. G. and Macoueen R. W. (1984) Precipitation of sulfide ores and organic matter: sulfate reactions at Pine Point. Science 224, 63-66.

Púttmann W., Hagemann H. W. Merz C. and Speczik S. (1988) Influence of organic material on mineralization processes in the Permian Kupferschiefer Formation, Poland. Org. Geochem. 13, 357-363.

Robie R. A., Hemingway B. S. and Fisher J. R. (1978)
Thermodynamic properties of minerals and related substances at $298.15 \mathrm{~K}$ and 1 bar $\left(10^{5}\right.$ pascals) pressures and at higher temperatures. U.S. Geol. Survey Bull. 1452.

Russell N., Seaward M., Rivera J. A., McCurdy K., Kesler S. E. and Cloke P. L. (1981) Geology and geochemistry of the Pueblo Viejo gold-silver oxide ore deposit. Inst. Min. Met. Trans., Sec. B 90, B153-B162.

Russell. N., Polanco J. and Kesler S. E. (1986) Geology of the Monte Negro gold-silver deposit, Pueblo Viejo district, Dominican Republic. In Proceedings of Gold '86, an International Symposium on the Geology of Gold (ed. A. J. MacDonald), pp. 497-503. GOLD '86.

SEWARD T. M. (1973) Thio complexes of gold in hydrothermal ore solutions. Geochim. cosmochim. Acta 37, 379-399.

SHENBerger D. M. and BarNes H. L. (1986) Gold solubility in aqueous sulfide solutions. Geol. Soc. Am. Abst. Prog. 18,748 .

Sillitoe R. H. and Bonham H. F. JR. (1984) Volcanic landforms and ore deposits. Econ. Geol. 79, 1286-1298.

Simoneit B. R. T. (1988) Petroleum generation in submarine hydrothermal systems: an update. Can. Mineral. 26, 827-840.

Sinninghe Damste J. S., De Leeuw J. W., Kock-Van Dalen A. C., De Zeeuw M. A., De Lange F., Rujpstra W. I. C. and SCHENCK P. A. (1987) The occurrence and identification of series of organic sulphur compounds in oils and sediment extracts. I. A study of Rozel Point Oil (U.S.A.). Geochim. cosmochim. Acta 51, 2369-2392.

Sinninghe Damsté J. S., Eglinton T. I;, De Leeuw J. W. and SCHENCK P. A. (1989) Organic sulphur in macromolecular sedimentary organic matter: I. Structure and origin of sulphur-containing moieties in kerogen, asphaltenes and coal as revealed by flash pyrolysis. Geochim. cosmochim. Acta 53, 873-889.

Smith R. M. and MarTell A. M. (1976) Critical Stability Constants, Vol. 4, Inorganic Complexes. Plenum Press.

Spiro C. L., Wong J., Lytle F. W., Greegor R: B., MAYLoTte D. H. and LAMSON S. H. (1984) X-ray absorption spectroscopic investigation of sulfur sites in coal: Organic sulfur identification. Science 226, 48-50.

Stern E. A., Elam W. T., Bunker B. A., Lu K. Q. and HeALD S. M. (1982) lon chambers for fuorescence and laboratory EXAFS detection. Nucl. Instrum. Meth. Phy. Res. 195, 345-346.

Tremaine P. R. and Leblanc J. C. (1980) The solubility of magnetite and the hydrolysis and oxidation of $\mathrm{Fe}^{2+}$ in water to $300^{\circ} \mathrm{C}$. J. Sol. Chem. 9, 415-442.

Wagman D. D., Evans W. H., Parker V. B., Schumm R. H., Halow l., Bailey S. M., Churney K. L. and NutTALL. R. L. (1982) The NBS table of chemical thermodynamic properties. Selected values for inorganic and $C_{1}$ and $\mathrm{C}_{2}$ organic substances in SI units. J. Phys. Chem. Ref. Data 11 (supp. 2).

Waldo G. S. and Penner-Hahn J. E. (1990) Sulfur in petroleums: Speciation by $X$-ray absorption near-edge spectroscopy. In preparation.

Wolery T. J. (1983) EQ3NR A computer program for geochemical aqueous speciation-solubility calculations: User's guide and documentation. UCRL-53414, Lawrence Livermore National Laboratory. 